\title{
THE ESSENCE AND SOCIO-SPIRITUAL CHARACTERISTICS OF PILGRIMAGE TOURISM
}

\author{
Bahrom Orzikulov \\ Researcher National University Of Uzbekistan
}

\section{ABSTRACT}

The article describes the essence of pilgrimage tourism and its socio-spiritual description. It spoke about the role, opportunities and prospects of pilgrimage tourism in the spiritual and moral development of people in Uzbekistan. The article was written on the basis of comparative analysis, objectivity, questionnaire, sociological survey, systematic analysis, chronological study of socio-political, spiritual events and phenomena, based on sources and evidence. Scientific research methods such as systematization, comparative analysis, problem-chronological and interdisciplinary approach were used. The article also uses scientific research methods such as systematization, comparative analysis, problem-chronological and interdisciplinary approach.

KEYWORDS: - Pilgrimage, pilgrimage tourism, socio-spiritual, object, monuments, religious, local, republican, international, infrastructure, culture, economic.

\section{INTRODUCTION}

Tourism is one of the most important sectors in the socio-spiritual life of the country, its economic development and enhancing its global prestige. Every country develops different areas of tourism based on its domestic capabilities, potential, geographical location, socio-economic status, history and present. Today, such areas as "ecotourism", "sports tourism", "excursion tourism", "extreme tourism", "hydronomic tourism", "cultural tourism", "pilgrimage tourism: are developing around the world. Uzbekistan, as one of the important cradles of world civilization, is one of the countries with a huge material and cultural heritage, which has long made a significant contribution to world civilization and development. As in other regions of the world, various areas of tourism are developing in the country. In this regard, our state has gained unique experience and pays attention to domestic and international tourism at the level of state policy.

\section{The MAIN FINDINGS AND RESULTS}

. As a new direction of tourism, one of the areas that can be particularly cost-effective is pilgrimage tourism. Pilgrimage tourism is one of the most favorable areas for improving the economic situation of each region, the organization of socio-spiritual life of the people. In recent years, a great deal of experience has been gained in the field of tourism promotion in the country, the inclusion of unexplored cultural heritage sites in the state register, the extensive use of tourism potential of the country. An important event was the organization of the "First International Forum on Pilgrimage 
CURRENT RESEARCH JOURNAL OF HISTORY 2(10): 24-26, October 2021

DOI: https://doi.org/10.37547/history-crjh-02-10-06

ISSN 2767-472X

(C)2021 Master Journals

\section{Crossref dof 81 Google}

Accepted 22th October, 2021 \& Published 27 ${ }^{\text {th }}$ October, 2021

Tourism" in February 2019 in Bukhara [1].

This is because the objects of pilgrimage tourism play an important role as sacred places that embody the national values, material and spiritual culture of each nation. Historical and cultural monuments play an important role in the formation and development of spiritual views in the human mind, in inculcating it in the minds of people. At the present time, when huge reforms and innovations are being carried out in all spheres, special attention is being paid to the development of pilgrimage tourism in our country. In recent years, the use of the term "pilgrimage tourism" in the press and in everyday communication has become widespread. This indicates that this area is receiving attention at the level of public policy.

Now about the meaning of the concepts of pilgrimage and pilgrimage tourism. According to the National Encyclopedia of Uzbekistan, the concept of pilgrimage is defined as going to holy places, graves and cemeteries to perform certain rituals. According to the Islamic creed, when visiting the tombs of saints, it is not permissible to ask for help from their souls, to satisfy their needs, to cure ailments, or to give birth to children. Because it is up to Allah alone to carry out such actions. Whether the pilgrims are prophets, saints or sheikhs of the sect, instead of asking them for salvation, it is appropriate to bless their rights and give the rewards of charity to their souls. In Islam, the worship of the individual is shirk. Muhammad (pbuh) said in a hadith: "Visit the graveyards, for it is a reminder of the Hereafter" It is said that remembering the Hereafter removes one from evil and brings one closer to goodness [2. P. 95].

According to the Uzbek dictionary, a pilgrim is a person who has visited or is going to visit these holy places, and those who returned from the pilgrimage brought souvenirs from those places [3. P. 148].
As for the essence of pilgrimage tourism, this field has entered the social life of our country and the spiritual life of our people as a new term in recent years, that is, it has become an important consumer term in our language. Tourism experts have commented on how Muslims should be able to travel for any reason without compromising their religious beliefs.

That is, the issue of using different terms on the basis of different opinions on this issue was raised. Among such concepts it is appropriate to include pilgrimage tourism, Islamic tourism, religious tourism, Sharia tourism, halal tourism, etc.

However, there are also some problematic aspects to all of the above terms. That is, when it comes to pilgrimage tourism, for example, most Muslims only understand Hajj and Umrah, Islamic tourism and religious tourism do not cover travel and leisure, not all travel can be fully Shariah, and so on. Due to various debates and discussions, the term Muslim-friendly travel has been preferred based on the views of religious and tourism experts [4].

In the Western literature, the definition of this term is slightly different, including According to A. Babkin, pilgrimage tourism is a visit to holy shrines, cities, cemeteries and sacred places in terms of respect and belief in the religion of different denominations [5. P. 11-12].

The Law of the Republic of Uzbekistan "On protection and use of cultural heritage sites" stipulates that pilgrimage tourism is considered sacred only in places where only religious scholars and saints live, but also places of interest - a common product of human and natural creation, as well as areas of historical, archaeological, urban, aesthetic, ethnological or anthropological value, and places where various ceremonies are performed are included in such places [6]. 
CURRENT RESEARCH JOURNAL OF HISTORY 2(10): 24-26, October 2021

DOI: https://doi.org/10.37547/history-crjh-02-10-06

ISSN 2767-472X

(C)2021 Master Journals

Crossref dof 81 Google

Accepted 22 ${ }^{\text {th }}$ October, 2021 \& Published 27thOctober, 2021

Thus, the shrines, which are the objects of pilgrimage tourism, as objects of material and cultural heritage, as a monument, as a set of ideas that embody the age-old dreams, aspirations and traditions of the people, have been calling people to goodness for centuries. In order to meet the spiritual needs of our people and to find religious comfort, they visit various shrines and shrines, where they perform various ceremonies and form a sense of fulfillment of their duties in this regard, says F. Akchaev [7. P. 55].

\section{Conclusion}

In general, the development of pilgrimage tourism in Uzbekistan requires a comprehensively coordinated integrated approach. It is necessary to involve all interested organizations and institutions involved in this work. This will prevent mistakes that may occur in the development of pilgrimage tourism. Particular attention should be paid to enterprises and organizations whose main activity is pilgrimage tourism. In our opinion, the development of these enterprises and organizations should be supported by the state and society. The issue is licensing and registration of shrines, solving the necessary infrastructure problems here.

\section{REFERENCES}

1. "The first international forum on pilgrimage tourism". Buxoro. February 22, 2019.https://www.gazeta.uz.

2. National Encyclopedia of Uzbekistan.Tashkent, 2006. -P 95.

3. Annotated dictionary of the Uzbek language. Volume 2 - Tashkent: UzME, 2006.- P.148.

4. https://azon.uz/content/views/ziyoratturizmi-islomiy-turizm-diniy-tur

5. Babkin A. Special tours of tourism. Tutorial. -
Rostov on Don: Soviet sport, 2008. - P. 11-12; Yana Karang: Dictionary of Tour Terms // http://uletaemru.ru.

6. Law of the Republic of Uzbekistan on protection and use of cultural heritage sites. // Bulletin of the Oliy Majlis of the Republic of Uzbekistan, 2001, № 9-10, Article 180; // Collection of Legislation of the Republic of Uzbekistan, 2004.

7. Akchaev F. Holy shrines and shrines of Jizzakh oasis. (Ethnosociological research). Doctor of Philosophy in History.-Tashkent. 2019. - P 55. 